no longer have to unlock secrets previously inaccessible. The extreme version of the Gallois doctrine, from time to time echoed by China (although not recently), that stability is best assured if every state is a military nuclear power, is unlikely to command support, but there are likely to be many governments itching to set off on the nuclear road. If the NPT was a bargain between nuclear and non-nuclear states, it will have to be remade. So why not dust off and redraft the US plan for the control of nuclear weapons put to the United Nations in 1946? The underlying theme, that sources of uranium should be owned internationally, predictably came to nothing then, but administrative control of nuclear materials must be a more reliable way of spotting illicit diversions, especially if, by then, the prospect of climatic change makes the resurgence of civil nuclear power essential.

\section{One boycott down}

Changed circumstances in South Africa will soon compel changed attitudes elsewhere than in Pretoria.

President F. W. De Klerk appears to have surprised his critics, not to mention his friends in South Africa, by his announcement last week that the African National Congress is to be legitimized again. In many ways as important, other political parties are no longer banned, while censorship and the death penalty are abolished. These are brave, if dangerous, steps forward. The intention is that there should be serious negotiations leading to the abolition of apartheid and a new constitution within five years. The process will begin when Mr Nelson Mandela, imprisoned for a quarter of a century, is released.

Two cautionary lessons must be drawn from this sequence of events, one of which is that even the most tyrannical regimes run serious risks in throwing their political opponents into goal. An earlier Soviet government discovered that by packing off the late Andrei Sakharov to Gorky. De Klerk has learned what his predecessor might have guessed, that political prisoners supported by the international community can write their own conditions for release. The second is that the abolition of apartheid is not simply a legislative matter, although a flood of legislation will be needed. (The South African government would be well advised to begin with a bill of rights, letting the courts shoulder the main burden of its work by striking down the practice of apartheid.) The success of this ambitious programme will hang on the degree to which the white minority (a third of the total) is willing to anticipate the goals now spelled out.

In that process, the international community is also engaged, both commercially and intellectually. An article on page 505 of this issue, for example, argues that ambitions in the past several years to enforce a blanket academic boycott on South Africa are mistaken (which this journal has always held), and that other forms of external pressure are likely to be more effective (and more just). But now the question is when these and other implied sanctions against South African institutions should, in any case, be lifted. Most people will say, "but not just yet". But what happens when Mandela is released? Then those who have argued for an academic boycott must logically turn their arguments upside down. If, when there was too little sign of change in South Africa, boycott could be held justifiable, do not the changed circumstances make free intellectual exchange both seemly and constructive?

\section{Biotechnology eclipsed?}

Genentech's rescue by Roche should raise questions about the procedures for approving new drugs.

WHATEVER has happened to biotechnology? Last week's arrangement between Hoffman-La Roche, the Swiss pharmaceutical manufacturer, and Genentech of California, is a surprise, but not a big surprise (see page 495). Like Biogen, the victim of earlier and deeper misfortunes, but also the other conspicuous star among the constellation of ambitious new biotechnology companies ten years ago, Genentech has learned the hard way how great is the cost of bringing new drugs to the market. For practical purposes, the company has two marketable products to show for ten years' hard work. During that time, it has built up an enviable reputation for the breadth of its laboratory investigations and for its readiness to devote resources to the investigation of common problems - and to publish the results. But, plainly, reputation is not simply converted into dollars; two years ago, Genentech's tissue plasminogen activator was kept waiting for six months by the Food and Drug Administration while a scientific opinion was supported by the prescribed data.

While some in the United States will regard this new development as yet another offence against the stars and stripes, others of a more reflective spirit may rightly ask whether Genentech's troubles derive from the arrangements now in force for the registration of new drugs. It is proper and prudent that synthetic chemicals believed to be effective against this or that disease should be put through the now-familiar system of toxicity and efficacy tests in animals and human beings. But is the full and expensive apparatus of these enquiries necessary when the materials on trial are intended to be identical with those produced naturally in normal human beings? So far, thanks to the measures taken to avoid public anxiety concerning recombinant-DNA techniques in the 1970s, the products of genetic manipulation have been put through the same rigorous and probably over-rigorous mill. How many more Genentechs will have to seek safety in the arms of bigger companies before this practice is recognized as the modern equivalent of the quaint British practice of sending a man with a red flag in front of the early railway locomotives?

NATURE $\cdot$ VOL $343 \cdot 8$ FEBRUARY 1990 